\title{
GEOGRAPHY AND REGIONAL SCIENCE: INTERDISCIPLINARY DISCIPLINES OF AREA ANALYSIS
}

\author{
Barry M. Moriarty*
}

\section{THE HISTORICAL RELATIONSHIP BETWEEN GEOGRAPHY AND REGIONAL SCIENCE}

Regional science came into being in the 1950s at the same time that some geographers were questioning their discipline's overriding concern with merely describing the similarities and differences among areas. These geographers were interested in determining the processes that gave rise or dissolution to geographic patterns. Such processes involved the interaction of different entities within the same area (ecological systems) as well as those that affected areas from outside (spatial systems). They were particularly interested in grounding geography in a body of theory that would explain the geographic location, distribution, pattern, and association of phenomena. The fact that for decades geography had disdained an interest in developing theoretical underpinnings resulted in the origin of regional science.

Within geography at the time, heated debate was rampant at annual meetings and in journals between traditional geographers and the new breed of "quantifiers," or those who were concerned with making the study of the human side of geography as scientific as the physical side. This ongoing debate centered around whether geography should give up its long-standing practice of being an idiographic discipline, interested in describing areas and regions as unique places, or a nomothetic discipline, interested in the search for generalizations, principles, and theoretical concepts that could be applied to explaining the patterns found in numerous areas and regions. The debate also centered on the methods of analysis: whether geographic analysis should be more phenomenological in approach or follow some form of positivism, although not logical positivism.

Many people have the mistaken belief that scientific research is always conducted according to some Baconian process of logical positivism (Marcus, Abler, and Olsen 1992). This belief is far from true when dealing with the social scien-

* Professor of Economic Geography, Department of Geography, University of North Carolina at Chapel Hill. The writing of this paper was supported by the National Science Foundation under grant number SES-9100492. 
ces. Unlike the objects studied in the physical sciences, people and social institutions have the ability to choose options and change behavior.

This circumstance has led to the formation of such post-logical positivist approaches to scientific inquiry as empiricism, instrumentalism, materialism, objectivism, pragmatism, reductionism, and rationalism (Moriarty 1983). The approaches, while difficult to define collectively, strive to identify the objectively determined principal factors that account for the existence of phenomena and show how the principal factors are functionally related to each other. The intent is to provide generalizations and theoretical models that are useful for empirical application. Generalizations and theories in the social sciences, compared to the physical sciences, are tendencies rather than absolutes and probabilistic rather than deterministic. Humanistic approaches to inquiry, on the other hand, such as phenomenology and its approaches-existentialism, transcendentalism, hermeneutics, and experientialism-rely on the subjectively, intuitively, or reflectively determined factors that are believed to form the essence of the phenomenon or govern its behavior. Humanistic approaches do not develop theories or generalizations, but merely describe and explicate phenomena without presuppositions. Being a practitioner of the scientific mode of enquiry does not imply that one does not have a commitment to humanitarianism or is not interested in the humanities.

During this period of the 1950s, the urban settlement began to be recognized by geographers as a region in its own right. Different groups of scholars, other than geographers, began to carve out niches to suit their interests. They allocated the study of countries to geography, regions within countries to regional science, and settlements within regions to ekistics. But, regardless of how they decided to apportion different geographic areas, geography has always been involved in the study of the total or any part of the man-environment system within a spatial context, which includes all geographic divisions of the earth at whatever scale.

\section{THE STRUCTURE OF GEOGRAPHY AND REGIONAL SCIENCE}

Appreciating the different viewpoints and the knowledge necessary to realize the sum total of the processes that interplay among each other within regions requires some understanding of the structure of geography as a discipline. During the first half of the century, a geographer could be expected to be knowledgeable about several subfields of the discipline. Geography was not only said to be the discipline that bridged the physical and human sciences, but was also said to be the study of cultural landscape by some, the study of human ecology by others, and the study of area differentiation by still others. 
Important subjects of concentration at the time were land use patterns, the location of commodity production, and regional studies dealing with the physical environment, people, and what people did for a living. Most geographers would be characterized as generalists. As knowledge expanded in every academic discipline, some geographers narrowed their interest to one or two of the many physical or social subfields of the discipline (Figure 1). To become well-grounded specialists in their subfields, they began to study the literature in their corresponding academic disciplines to better understand the aspatial processes that dealt with geographically arrayed phenomena developed by these disciplines. For example, economic geographers studied economics, population geographers studied demography, and social geographers studied sociology.

Consider the function $Y=f\left(X_{1}, X_{2}, \ldots X_{n}\right)+e$, which expresses the relationship between some geographically arrayed phenomena (Y) (e.g., labor force participation rates by county, the rate at which people were infected by some contagious disease by enumeration district, or the population change by BEA area). Consider also several variables $\mathbf{X}_{\mathbf{i}}$ that are used to explain the various phenomena (e.g., industrial mix, age, education, blood chemistry, unemployment rate, etc.). The scientific geographer would focus attention on the residual values (e) by mapping them to see if a particular geographic pattern emerged (whether positively spatially autocorrelated, negatively spatially autocorrelated, or randomly distributed spatially) that would provide clues to some other geographic variable involved in the process-perhaps distance to a major city, airport, or interstate highway system. Such a variable would be one that improved the explanatory power of the relationship by adding a new component to the process or by replacing an old component that was no longer significant in the presence of the new one.

Testing the validity of these new theories and propositions required more than mere description; it required a knowledge of numerous multivariate statistical procedures and other mathematical frameworks and methodologies. At the time, the social science disciplines that were making advances in theory development and mathematical modeling and were of interest to scientific geographers were in several subfields of economics, sociology, civil engineering, planning, demography, and statistics. Geographers more aligned with history, anthropology, and political science subfields were more interested in a humanistic approach to the study of geographic phenomena.

Regional science was born out of a need for a more analytical approach to examining regional phenomena and to advance the development of theory and methodology to help expand knowledge and understanding of regional phenomena and problems, whatever the geographic scale. To date, however, regional science has only focused on a narrow portion of the total range of processes that 


\section{FIGURE 1}

Physical and Human Academic Disciplines Contributing to the Development of Knowledge and Understanding about Regions

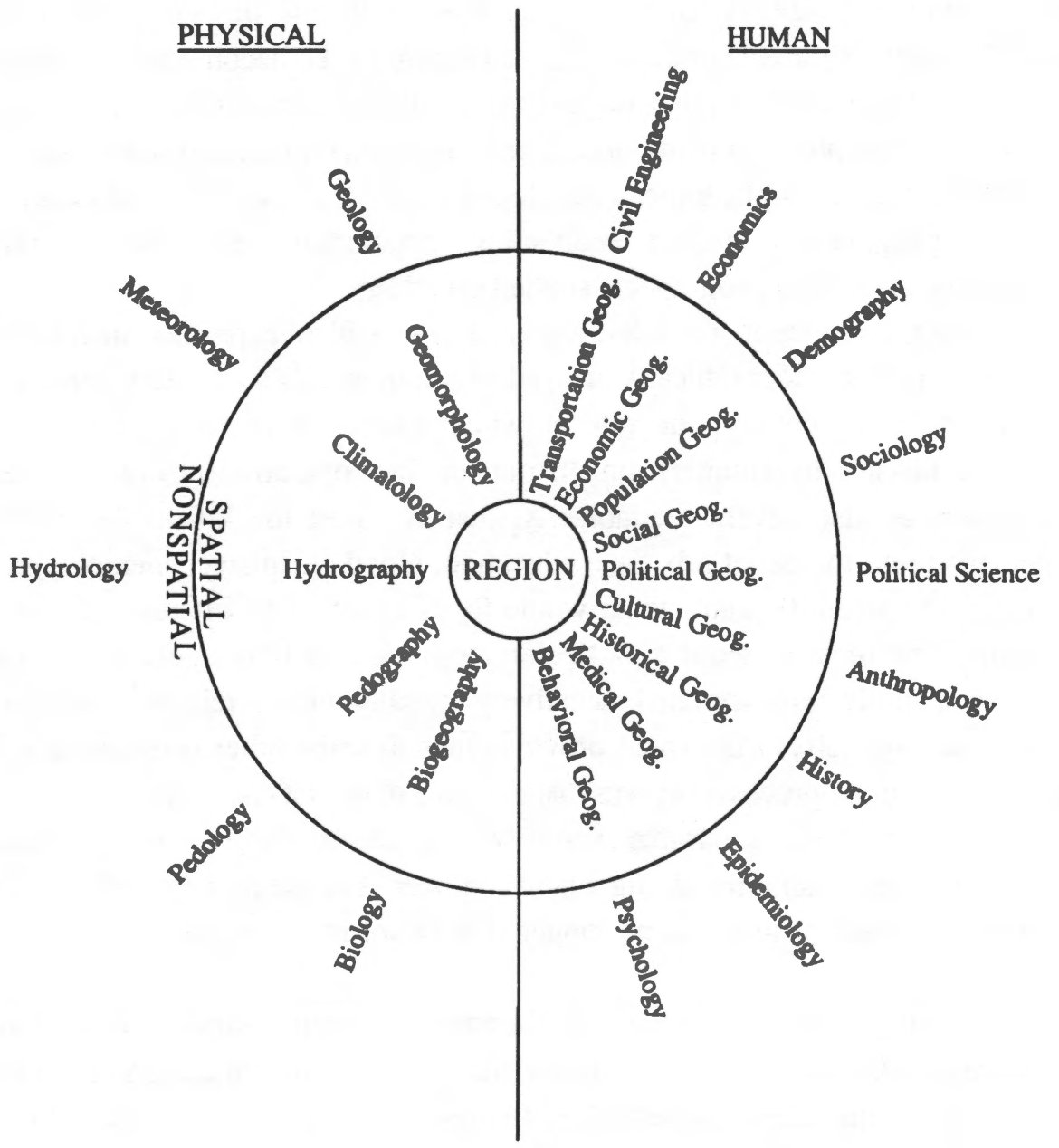

contribute to the functioning of a region-primarily those that examine economic phenomena (input-output and other econometric models that deal mostly with changes in sector employment levels, capital flows, investment outcomes, and international trade, for example). Other contributions have been associated with demography (migration and moving patterns), sociology (housing and residential neighborhood patterns), and civil engineering (location-allocation modeling and transport network development and analysis).

In terms of providing more reliable knowledge of how a region functions, regional science has only provided a limited amount of the understanding that is 
needed. Scholars from other disciplines, currently underrepresented in regional science but interested in geographically arrayed phenomena, need to be more aware of regional science. In the early years, political scientists and sociologists made up a significant number of regional scientists but dropped out as time went by. It should be emphasized that those that argue that regional science has served its purpose need to be made aware that as long as the concept of a region is important in the thinking of people, there will be a need for regional science, just as there will always be a need for geography.

\section{SOME RECIPROCAL CONTRIBUTIONS OF GEOGRAPHY AND REGIONAL SCIENCE}

Very few regional scientists obtained their education and training totally in regional science. It was, and still is, the regional scientists associated with other disciplines who have contributed most to the development of regional science theory and methodology. In the history of science, it has been found that the important scientific contributions were not realized until many years after the contributions were made. Note the Nobel Prizes, for example. In many cases, those contributions that were thought important at the time were not self-sustaining over the long run. ${ }^{1}$ The theoretical contributions of Ricardo (1817), von Thunen (1826), Weber (1909), Christaller (1933), and Losch (1939) are as basic to regional science as they are to economic geography and regional economics. On the other hand, macro mathematical models such as those associated with social physics (gravity and spatial interaction models) have been found to be less than satisfactory in the development of spatial theory (for example, Stewart and Werntz 1958). That is not to say that they are not completely useless as forecasting instruments for such purposes as allocating projected retail sales among different shopping centers, projected traffic flows among intraurban and interurban highway routes, new residential housing units to different areas of the city, or international capitol investments or trade flows among countries.

A large number of regional scientists outside the field of geography, particularly those associated with location theory, the spatial structure of urban and regional development, spatial interaction theory, and spatial forecasting models, have made significant contributions to the development of geographic or spatial theory. It is impossible to name the many scholars who have made important contributions over the years in the United States alone, not to mention those from other countries. High on the list of U.S. contributors, by their major field of contribution, are 
1. Industrial and commercial location theory: Walter Isard $(1958,1960)$, Melvin Greenhut (1956), Benjamin Chinitz (1961), Martin Beckman (1968), Benjamin Stevens (1961), Edgar M. Hoover (1948), Leon Moses (1960), and Charles Tiebout (1957).

2. Residential housing markets and location theory: Otis Dudley Duncan (1955), Richard Muth (1969), Eshref Sherky (1955), Stanley Lieberson (1963), Charles Tilly (1960), and Wendell Bell (1959).

3. Transportation, spatial interaction, and network location theory: Gerald Carrothers (1956) and Lowdon Wingo, Jr. (1961).

4. Urban land use, growth theory, and modeling: Charles Leven (1970), Edwin Mills (1972), Kingsley Davis (1965), John Kain (1964), John Niedercom (1963), William Alonso (1965), Stewart Chapin Jr., (1966), William Weaton (1964), and Ira Lowry (1964).

5. Regional growth theory and modeling: Alfred Hirschman (1958), John Friedman (1964), Niles Hansen (1977), Harvey Perloff (1963), William Miemyk (1965), and Harry Richardson (1969).

6. Agricultural location theory: Edgar Dunn (1970).

7. Migration patterns: Michael Greenwood (1970).

Many of these social scientists made contributions in other areas of spatial theory as well.

An equally impressive list of geographers in the United States have made important contributions to regional science. Contributions to the various fields were

1. Industrial and commercial location theory: Rodney Erickson (1979), John Rees (1979), Edward Malecki (1979), and Alan Pred (1977).

2. Residential housing markets, migration, and moving: William A.V. Clark (1979) and Lawrence Brown (1981).

3. Location decision making and spatial choice modeling: Julian Wolpert (1965), Gerard Rushton (1969), and Reginald Golledge (1970).

4. Geographic diffusion and flows: Lawrence Brown and R. L. Sanders (1981), Richard Morrell (1968), and Waldo Tobler (1965).

5. Transportation, spatial interaction, and network location modeling: Richard Church (1973), William Garrison (1966), Susan Hanson (1980), Kingsley Haynes (1975), Charles ReVelle (1970), and William Werntz (1966).

6. Urban land use, growth theory, and modeling: Brian Berry (1961), Arthur Getis (1963), Allen Scott (1969), Eric Sheppard (1976), Edward Ullman (1955,1971), and Emileo Casetti (1973).

7. Regional growth theory and modeling: Brian Berry (1968) and John Borchert (1972).

8. Human environmental problems: Robert Kates (1971). 
And, while input-output analysis is not of too much interest to geography, William Byers (1978) has made important contributions to regional science in developing spatial input-output models. Most of these geographers were major contributors to the development of contemporary scientific geography in the world. Some have served as members of the National Academy of Science, and some have served as presidents of the Regional Science Association and the Association of American Geographers.

\section{CONCLUSIONS}

What regional science did most for geography was to provide a forum for the ideas and methodologies of scientific human geographers that were not and are apparently still not acceptable to a large number of geographers. Scientific geographers' ideas and methods of analysis were and are accepted in regional science because many other practitioners of regional science are interested in the same ideas and methods. Thus, there exists a reciprocal appreciation between scientific geographers and practitioners of other disciplines interested in regional science.

That scientific geographers are not as influential in geography as their humanistic counterparts can be seen in two ways. First, many geographers who have made outstanding contributions to knowledge concerning questions of basic scientific inquiry and of practical importance to geography and who have been nominated for offices in the Association of American Geographers have been defeated, more so in recent years. Second, in the last major ranking of social science graduate departments in the United States by the National Academy of Sciences, the range of rankings for geography departments was much smaller than for any other discipline. Faculty in largely humanistic geography departments ranked largely scientific departments low on the scale and vice versa. Overall, humanistic departments were ranked somewhat higher than scientifically oriented departments. Scientific geographers found it difficult to have their papers published in geographic journals and looked to other publications as outlets for their research findings. By the mid 1980s, the situation resulted in an invitation being sent to several hundred scientific geographers to meet in Athens, Georgia, to discuss organizing the American Association of Scientific Geographers. While no new association resulted from the meeting, the fact that it was convened demonstrated the alienation felt by scientific geographers in their own discipline. It is, however, the scientific geographers and the scientific departments that are responsible for attracting the greatest share of extramural funds to geography. 
Unfortunately, the same intolerance that exists in geography against scientific geographers exists in regional science toward scholars in other disciplines as well. In the early days of regional science, a significant number of political scientists and sociologists participated at meetings and were members of regional science associations. As time went by, the numbers decreased. Political scientists and sociologists found a lack of acceptance of their ideas by the more economictrained regional scientists: those that seem only able to seek explanation within a cost minimizing, profit maximization, or general equilibrium approach. Their lack of appreciation for the nonfinancial and nonmonetary theoretical concepts and principles of political scientists and sociologists who prescribed cultural social institutions as being important to any explanation of human geographic phenomena resulted in the decrease in representation of these disciplines in regional science. This lack of appreciation is also seen in the published works of many economicminded regional scientists who obtain ideas from the empirical studies of colleagues in other disciplines, but only reference members of their own discipline in their bibliographies.

To fully understand the region scientifically, regional science must encourage members of other disciplines interested in area analysis to join the important ongoing interdisciplinary study of regions. In addition, future research is needed to expand knowledge and understanding of how individuals make choices among different geographically located alternatives. Aggregate macro spatial models have considerably limited use compared to micro models of individual spatial choice. Such micro models have applicability to numerous problems that deal with the location of both public and private facilities. Research on this frontier will best be accomplished by a multidisciplinary approach encompassing numerous social science disciplines within regional science.

\section{ENDNOTES}

1. No survey was conducted to determine which geographers and regional scientists had the greatest influence on each others' disciplines. Another writer would produce a different list of names, but many of the same people would be on everybody's list. This list is based upon those scholars that have greatly influenced my education and thinking over the past 25 years. Several scholars were gleaned from the original list for the sake of brevity. This list also purposely leaves out younger scholars and research studies that have emerged in the past 10 years in keeping with the test of time paradigm. 


\section{REFERENCES}

Only one publication is cited for each scholar from among the many each has published. In the case of a few individuals who have made numerous contributions to more than one subfield of research, one publication from each subfield is cited. The Social Science Citation Index was not consulted for the most cited publication of each scholar.

Alonso, W. Location and Land Use: Toward a General Theory of Land Rent. Cambridge: Harvard University Press, 1965.

Beckmann, M. Location Theory. New York: Random House, 1968.

Bell, W. "Social Areas: Typology of Urban Neighborhoods." In Community

Structure and Analysis, edited by M. B. Sussman. New York: Thomas Y. Crowell Company, 1959.

Berry, B. J. L. "City Size Distribution and Economic Development." Economic Development and Cultural Change 9 (1961): 573-588. . "Interdependency of Spatial Structure and Spatial Behavior: A General

Field Theory Formulation." Papers: Regional Science Association 21 (1968): 205-228.

Beyers, W. B. "On the Structure and Development of Multi-Regional Economic Systems." Papers: Regional Science Association 40 (1978): 109-134.

Bochert, J. R. "America's Changing Metropolitan Regions." Annals: Association of American Geographers 62 (1972): 352-373.

Brown, L. A. Innovation Diffusion: A New Perspective. London: Methuen, 1981.

Brown, L. A., and R. L. Sanders. "Toward a Development Paradigm of Migration with Particular Reference to Third World Settings." In Migration Decision Making: Multidisciplinary Approaches to Micro-Level Studies in Developed and Developing Countries, edited by G. F. DeJong and R. W. Gardner, 149-185. New York: Pergamon Press, 1981.

Carrothers, G. A. P. "An Historical Review of the Gravity and Potential Concepts of Human Interaction." Journal of the American Institute of Planners 22 (1956): 94-102.

Casetti, E. "Testing for Spatial-Temporal Trends: An Application to Urban Population Density Trends Using the Expansion Method." Canadian Geographer 17 (1973): 127-137.

Chapin, S. F., Jr. Urban Land Use Planning. 2d ed. Urbana: University of Illinois Press, 1966.

Chinitz, B. "Contrasts in Agglomeration: New York and Pittsburgh." Papers: American Economic Review 51 (1961): 279-289. 
Christaller, W. Die Zentralen Orte in Sudduetschland. Jena: Gustav Fischer, 1933. Translation by C. W. Baskin, Central Places in Southern Germany. Englewood Cliffs, N. J.: Prentice-Hall, 1966.

Church, R., and C. Revelle. "The Maximal Covering Location Problem." Papers: Regional Science Association 32 (1973): 101-118.

Clark, W. A. V., and T. R. Smith. "Modeling Information Use in a Spatial Context." Annals: Association of American Geographers 69 (1979): 575-598.

Davis, K. "The Urbanization of the Human Population." Scientific American 213 (1965): 40-53.

Duncan, O. D., and B. Duncan. "Residential Distribution and Occupational Stratification." The American Journal of Sociology 60 (1955): 493-503.

Dunn, E. S., Jr. "The Equilibrium of Land-Use Patterns in Agriculture." In Spatial Economic Theory, edited by R. D. Dean, W. H. Leahy, and D. L. Modee, 233-250. New York: The Free Press, 1970.

Erickson, R. A., and T. R. Leinbach. "Characteristics of Branch Plants Attracted to NonMetropolitan Areas." In NonMetropolitan Industrialization, edited by R. E. Lonsdale and H. L. Seyler, 75-78. Washington, D.C.: V. H. Winston, 1979.

Feldman, A. S., and C. Tilly. "The Interaction of Social and Physical Space." American Sociological Review 25 (1960): 877-884.

Friedman, J. R. P., and W. Alonso. Regional Development and Planning. Cambridge: The MIT Press, 1964.

Garrison, W. L. "Difficult Decisions in Land Use Model Construction." Highway Research Record: Land Use Forecasting Concepts, No. 126. Washington, D.C.: Highway Research Board, 1966.

Getis, A. "The Determination of the Location of Retail Activities with the Use of a Map Transformation." Economic Geography 39 (1963): 1-22.

Golledge, R. G. "Some Equilibrium Models of Consumer Behavior." Economic Geography 46 (1970): 417-424.

Greenhut, M. L. Plant Location in Theory and in Practice. Chapel Hill: University of North Carolina Press, 1956.

Greenwood, M. J. "Lagged Response in the Decision to Migrate." Journal of Regional Science 10 (1970): 375-384.

Hansen, M. "Systems Approaches to Human Settlements." Papers: Regional Science Association 38 (1977): 17-32.

Hanson, S. "Spatial Diversification and Multipurpose Travel: Implications for Choice Theory." Geographical Analysis 12 (1980): 245-257.

Harris, C., and E. L. Ullman. "The Nature of Cities." The Annals of the American Academy of Political and Social Science 242 (1955): 7-17. 
Haynes, K. E. "Spatial Change in Urban Structure: Alternative Approaches to Ecological Dynamics." Economic Geography 47 (1971): 324-335.

Haynes, K. E., and W. T. Enders. "Distance, Direction and Entropy in the Evolution of a Settlement Pattern." Economic Geography 51 (1975): 357-365.

Hirschman, A. O. The Strategy for Economic Development. New Haven: Yale University Press, 1958.

Hoover, E. M. The Location of Economic Activity. New York: McGraw-Hill, 1948.

Isard, W. Location and Space Economy. Cambridge: The MIT Press, 1958.

Isard, W., et. al. Methods of Regional Analysis. Cambridge: MIT Press, 1960.

Kain, J. F. "The Development of Urban Transportation Models." Papers: Regional Science Association 14 (1964): 147-173.

Kates, R. W. "Natural Hazard in Human Ecological Perspective: Hypothesis and Models." Economic Geography 47 (1971): 438-451.

Leven, C. L., J. B. Legler, and P. Shapiro. An Analytical Framework for Regional Development Policy. Cambridge: MIT Press, 1970.

Lieberson, S. Ethnic Patterns in American Cities. New York: The Free Press of Glencoe, 1963.

Losch, A. Die Raumliche Ondmung der Wirtschaft. 1954. Translated by W. H. Woglom, The Economics of Location. New Haven: Yale University Press, 1939.

Lowry, I. S. A Model of Metropolis. Santa Monica, Calif.: The RAND Corporation, 1964.

Malecki, E. J. "Agglomeration and Intra-Firm Linkage in RBD Location in the United States." Tijdschrift voor Economische en Sociale Geografie 70 (1979): 322-332.

Marcus, M. G., in collaboration with R. F. Abler and J. M. Olson. "Humanism and Science in Geography." Geography's Inner Worlds, edited by R. F. Abler, M. G. Marcus, and J. M. Olson, 327-341. New Brunswick, N.J.: Rutgers University Press, 1992.

Miernyk, W. The Elements of Input-Output Analysis. New York: Random House, 1963.

Mills, E. S. Urban Economics. Glenview, Ill.: Scott-Foresman, 1972.

Moriarty, B. M. "'Science' and the Funding of Geographic Research: The Pursuit of Reliable Knowledge." Professional Geographer 35 (1983): 332-336.

Morrill, R. L. "Waves of Spatial Diffusion." Journal of Regional Science 8 (1968): 1-18. 
Moses, L. N. "A General Equilibrium Model of Production, Interregional Trade, and Location of Industry." Review of Economics and Statistics 42 (1960): 373-399.

Muth, R. F. Cities and Housing. Chicago: University of Chicago Press, 1969.

Niedercom, J. H. An Econometric Model of Metropolitan Employment and Population Growth. Santa Monica, Calif.: The RAND Corporation, 1963.

Perloff, H., et. al. Regions, Resources and Economic Growth. Washington, D.C.: Resources for the Future, Inc., 1963.

Pred, A. R. City Systems in Advanced Economics. New York: Halstead Press, 1977.

Rees, J. "Technological Change and Regional Shifts in American Manufacturing." Professional Geographer 31 (1979): 45-54.

Revelle, C., D. Marks, and J. C. Liebman. "An Analysis of Public and Private Sector Location Models." Management Science 16 (1970): 692-707.

Ricardo, D. The Principles of Political Economy and Taxation. London: John Murray (Albermarle St.), 1817. Reprint. New York: E. P. Dutton and Company, 1912.

Richardson, H. W. Regional Economics. New York: Praeger Publishers, 1969.

Rushton, G. "Analysis of Spatial Behavior from Revealed Space Preference." Annals: Association of American Geographers 59 (1969): 391-400.

Scott, A. J. "Spatial Equilibrium of the Central City." Journal of Regional Science 9 (1969): 29-46.

Sheppard, E. S. "Entropy, Theory Construction and Spatial Analysis." Environment and Planning 8 (1976): 741-752.

Shevky, E., and W. Bell. Social Area Analysis. Sanford: Sanford University Press, 1955.

Stevens, B. "Linear Programming and Location Rent." Journal of Regional Science 3 (1961): 15-26.

Stewart, J. Q., and W. Wamtz. "Physics of Population Distribution." Journal of Regional Science 1 (1958): 99-123.

Tiebout, C. "Location Theory: Emperical Evidence and Economic Evaluation." Papers: Regional Science Association 3 (1957): 74-86.

Tobler, W. R. "Computation of the Correspondence of Geographical Pattems." Papers: Regional Science Association 15 (1965): 131-142. - "Geographical Filters and Their Inverses." Geographical Review 1 (1970): 234-253.

Ullman, E. L., M. F. Dacey, and H. Brodsky. The Economic Base of American Cities. Seattle: University of Washington Press, 1971.

Warntz, W. "The Topology of Socio-Economic Terrain and Spatial Flows." Papers: Regional Science Association 17 (1966): 48. 
Weber, A. Uber den Standort der Industrien I: Reine Theorie des Standorts. Tubingen: Mohr. (1909). Translated by C. J. Friedrich. Theory of the Location of Industries. Chicago: University of Chicago Press, 1929.

Wingo, L., Jr. Transportation and Urban Land. Washington, D.C.: Resources for the Future, 1961.

Wolpert, J. "Behavioral Aspects of the Decision to Migrate." Papers: Regional Science Association 15 (1965): 159-172. 